\title{
The Relationship Between Corporate Social Responsibility and Profitability: The Case of Dangote Cement PIc
}

\author{
Murtala Zakari \\ Post Graduate School of Accounting and Finance, Leeds Beckett University, Leeds, UK \\ Email address: \\ murhafs2010@gmail.com, murhab2015@gmail.com \\ To cite this article: \\ Murtala Zakari. The Relationship Between Corporate Social Responsibility and Profitability: The Case of Dangote Cement Plc. Journal of \\ Finance and Accounting. Vol. 5, No. 4, 2017, pp. 171-176. doi: 10.11648/j.jfa.20170504.18
}

Received: May 9, 2017; Accepted: May 22, 2017; Published: July 26, 2017

\begin{abstract}
This study seeks to find out the relationship between corporate social responsibility (CSR) investment and profitability of Dangote Cement Plc using secondary data. The study assesses the impact of CSR investment on Dangote's increase in revenue, profit after tax (PAT), and earnings per share (EPS) over a period of 5years. To achieve this, data were obtained from Dangote's annual sustainability reports and accounts for the period of 2012-2016 and analyzed using content analysis such as tables, percentages and using the trend line analysis to get the linear correlation coefficient (R-square). Findings from the analysis show that there is a positive relationship between CSR investment and profitability. Thus, Revenue shows $67.81 \%$ degree of positive relationship, profit after tax (PAT) depicts $54.28 \%$ degree of positive relationship and $60.79 \%$ is attributed to the degree of positive relationship between Earning per share (EPS) and CSR investment of Dangote cement Plc within the observed period (2012-2016). The study concludes that Dangote's CSR investment is positively correlated with the profitability performance indicators.
\end{abstract}

Keywords: CSR, Profitability, Revenue, PAT, EPS, Dangote

\section{Background to the Study}

\subsection{Introduction}

Many researchers tried to identify the relationship between corporate social responsibility and financial performance but found varying results from positive and negative relationship to inconclusive results $[24,31,23,30]$. There are different views of the role of firms in society and disagreement as to whether wealth maximization should be the sole goal of a corporation [34]. However, society is questioning the basic reason for an organization's existence i.e. to create wealth. [17] opined that this narrow reason excludes creating value or justice for people, society and the environment. In response to these concerns, corporate social reporting is transforming and voluntary reporting is increasing to provide more useful information and corporate transparency and accountability [11]. According to investopedia.com, corporate social responsibility, often abbreviated "CSR," is a corporation's initiatives to assess and take responsibility for the company's effects on environmental and social wellbeing. The term generally applies to efforts that go beyond what may be required by regulators or environmental protection groups. CSR may also be referred to as "corporate citizenship" and can involve incurring short-term costs that do not provide an immediate financial benefit to the company, but instead promote positive social and environmental change. Organizations are being called upon to take responsibility for the impact of their operations on the host society and the natural environment. Organizations are also being asked to demonstrate the inclusion of social and environmental concerns in business operations and in interactions with stakeholders (Van Marrewijk \& Verre, 2003) as cited in [6].

The concept of measuring and reporting the three elements of an organization's social, environmental and economic impacts gained prominence during the late 1990s and early 2000s, which is credited to John Elkington,'s Triple Bottom Line ("People, Planet, Profit"), and which began the new non-financial reporting frameworks from a social and environmental perspective [17]. The concept of corporate social responsibility (CSR) asserts that corporations have an obligation to consider the interests of customers, employees, shareholders, communities, as well as the ecological 
"footprint" in all aspects of their operations [6].

As cited in [6], Shane and Spicer (1983) opined that firms, which actively account for the corporate social responsibility risk factor, are seen as less risky investments compare to the firms that ignore it. Consequently, on a risk-adjusted basis, their expected returns are predicted to be lower. Hamilton et al. (1993) cited in [6] opined that compliance with corporate social responsibility principles is not efficiently priced by market participants. A positive (negative) relation follows depending on the sign of the inefficiency. Hamilton et al (1993) argued that, if a sufficiently large number of investors underestimate (overestimate) probability that adverse events related to CSR issues might affect companies not complying with the CSR principles then their stocks will provide lower (higher) risk-adjusted return than socially responsible companies stocks.

Previous academic studies [9, 19, 3, 6, 21] have shown that the concept of CSR is a significant component for business success. The relationship between CSR and companies' financial performance has been inconclusive, controversial and open to further research. Thus, a gap exists in reaching a consensus on the relationship between CSR and profitability $[24,27]$

Using extensive data over a period of 5 years, this study aims to examine and test the relationship between CSR and profitability around CSR practices and policies of Dangote Cement Plc. Dangote Cement Plc is chosen because it is the Nigerian multinational industrial conglomerate, and largest conglomerate in West Africa and one of the largest on the African continent. It generated revenue in excess of US $\$ 3$ billion in 2015. Dangote Cement Plc is one of the leading diversified business conglomerates in Africa, and employs more than 26,000 people [29]. Dangote has presence in over 25 countries in African continent; it is one of the most diversified business conglomerates in Africa with a hardearned reputation for excellent business practices and products' quality with its operational headquarters in the bustling metropolis of Lagos, Nigeria in West Africa. Its activities encompass Cement Manufacturing, Packing \& Distribution [29]. Dangote's core business focus is to provide local, value added products and services that meet the 'basic needs' of the populace. Through the construction and operation of large-scale manufacturing facilities in Nigeria and across Africa, Dangote is focused on building local manufacturing capacity to generate employment and provide goods for the people [29]. The data set includes extracts from the annual reports and sustainability reports of Dangote Cement Plc and covers the period of 5 years (2012-2016). The relationship is tested by using simple statistical trend analysis.

\subsection{Research Questions}

1. Is there a relationship between changes in revenue in the last 5 years and CSR investment of the Dangote Cement Plc?

2. Is there a relationship between changes in profit after tax (PAT) in the last 5 years and CSR investment of the

\section{Dangote Cement Plc?}

3. Is there a relationship between changes in earning per share (EPS) in the last 5 years and CSR investment of the Dangote Cement Plc?

\section{Literature Review}

Corporate social responsibility is generally voluntary in nature and refers to activities that exceed a mere compliance with the law. The social and environmental responsibilities of enterprises may reflect the changing expectations of society [6]. Corporate social responsibility poses several challenges for enterprises, including the need to define their responsibilities with respect to those of the public sector, determine the extent of their obligations in the supply chain and decide until what point in the future they should anticipate and plan for the consequences of their activities, especially in the case of natural resource use [6]. Corporate social responsibility is what an organization does to contribute to the social, economic, political or educational development of the host community where it operates, but which the organization is not compelled to comply by any law [2]. In the same vein, [1] opined that corporate social responsibility is a business decision making linked to ethical values, compliance with legal requirements, and respect for people, communities, and the environment around the world. According to Marrewijk (2003) cited in [6] the concept of CSR covers three dimensions of corporate action such as economic, social and environmental.

Divergent theories predict conflicting directionality and a number of empirical studies have found inconsistent results in the study of CSR and financial performance. Previously, scholars within the neoclassical economics tradition argued theoretically that CSR strategies unnecessarily raise a firm's costs, thus creating a competitive disadvantage vis-à-vis competitors [14, 5, 26]. Similarly, neoclassical economists argued that firms should devote their energies to supplying goods and services to their customers, they should minimize costs and maximize profits; and all this should take place within the laws and regulations of the land [20]. In the same vein, proponents of this viewpoint argued that CSR is diversion from the main business of wealth-creation, blunting competition, and imposition of economic cost on firm and therefore, the social responsibility of business is to increase its profits [15].

Conversely, other scholars have argued that investment in CSR activities would enhance; profitability of corporations [4], higher quality employees [18], better marketing of products, services, and creation of unforeseen opportunities [13], and obtaining better resources [35]

Empirical evidence in a number of studies of corporate social responsibility and financial performance reveals mixed results;

[9] studied the relationship between CSR and corporate financial performance in Korea. A sample of 1222 firms was selected for a period of 7years (2002-2008). The researchers used an equal-weighted CSR index and a stakeholder- 
weighted index as proxies for corporate social responsibility (CSR), and return on assets (ROA), return on equity (ROE) and Tobin's $\mathrm{Q}$ as proxies for corporate financial performance. Using cross-sectional regression analysis, the result indicated a significant positive relationship between CSR and corporate financial performance in respect of stakeholderweighted index, but not on the equal-weighted CSR index.

[19] conducted a research on the impact of corporate social responsibility on financial performance of corporations in Pakistan. A sample of 156 listed companies on Karachi Stock Exchange (KSE) from textile sector, chemical sector, cement sector and the tobacco sector were surveyed for the period 2011 and 2012, using secondary data from annual reports and accounts, the study reveals that corporate social responsibility (CSR) has no effect on financial performance (CFP), and CSR has negative effect on the market value of the share but no relationship to debt/equity behavior of the firm. By and large, the investors do not have the same level of information as the information is captured by the management about the company affairs.

[3] investigated the causal relationship between CSR and profitability of banks in Nigeria using First Bank Nigeria Plc as a case study. Data from published annual reports and accounts of First Bank Nigeria Plc were collected and analyzed using regression analysis and the result indicated a positive relationship between CSR investments and the profitability of the bank.

[6] studied the relationship between CSR and profitability on the listed firms in the Nigerian Stock Exchange using secondary data. A sample of ten (10) firms was randomly selected for the period 1999-2008. Ordinary least square was used for the analysis of collected data and the result shows a negative relationship between CSR and profit after tax. The study also found that expenditure spent on corporate social responsibility(CSR) vary from one firm to another and the firms invested less than $10 \%$ of their annual profit on CSR.

[21] examined the relationship between CSR and firms' financial performance with focus on the Nigerian manufacturing sector, a sample of 20 firms were selected for the period of 2002-2011. The researchers used profit before tax (PBT) and annual turnover (AT) as proxies for financial performance. Correlation and regression analysis were conducted, the results revealed a significant relationship between CSR and PBT on one hand, and CSR and turnover on the other hand.

A reasonable explanation for the mixed results in the previous studies highlighted above could be the various ways corporate financial performance and corporate social responsibility have been operationally defined (Carroll, 1979 cited in [19]), or lack of appropriate statistical controls [23]. Similarly, some previous studies relied on various reputational indices, such as Moskowitz's (1972) tripartite ratings of 'outstanding', 'honorable mention', and 'worst' companies [10]. As cited in [19], another widely used index is the measure provided by the Council on Economic Priorities (CEP) based on social audit ranking of companies' pollution records (Bragdon and Marlin 1972; Fogler and Nutt
1975; Spicer 1978). Other reasons are over reliance on negative screening processes to establish the sample, the inclusion of limited number of accounting and market performance variables; small sample sizes; and short analysis periods [22]; and mismatch between social and financial variables [33].

\section{Research Methodology}

The objective of this study is to analyze if there is a relationship between CSR and profitability. This study bases its measurement of CSR on content analysis of the annual reports of Dangote Cement Plc. This method is similar to that used by [12] and [8]. The researcher used a case study approach and would analyze data from several key performance indicators as reported in Dangote Cement Plc's sustainability report and annual account for a period of 5 years (2012-2016). The use of secondary data is justified by the fact that written or printed document are more accurate and reliable in ascertaining compliance to principles in research work than primary data gathered through personal interview or questionnaire administration (Dandago and Muktar, 2003 cited in [36] )

\subsection{Variables}

The variables that will be used for the relationship between CSR and profitability are as follows.

\section{Profitability Variables}

The profitability variables that will be used in this research are

1. Revenue,

2. Profit After Tax(PAT)

3. Earnings Per Share (EPS).

These are proxies for profitability that will be analyzed against CSR investment in the social and environmental areas of responsibility of the study firm.

\section{CSR Variables}

The CSR variables or proxies that will be used in the analysis of this research will be carefully selected to represent major key performance indicators, which have values attached to them and are quantifiable. The CSR variables will include:

1. Social Investment (Education, Sponsorship and Donations),

2. Community Development Project.

The sum value of (1) and (2) above will be used as CSR investment costs in the analysis against each of the profitability variables defined above.

The variables are similar to that used by [8] and [12]

\subsection{Method of Analysis}

Data would be analyzed using simple statistical tools from Microsoft Excel such as tables and linear correlation coefficient using SPSS software. An equation model would be developed to draw a relationship between CSR and profitability. This would be achieved by using the trend line 
analysis to get the linear correlation coefficient (R-square). This method of analysis is consistent with the work of other researchers [12] and [8].

\section{Data Analysis and Discussion}

In this section, the tables and percentages used in the analysis of data collected are presented and used in analyzing the research questions.

Table 1. Profitability and CSR indicators of Social \& Environmental Costs.

\begin{tabular}{lllll}
\hline \multicolumn{2}{c}{ Profitability Indicators(\#'million) } & $\begin{array}{l}\text { CSR Indicator } \\
\text { (\#'million) }\end{array}$ \\
\hline Year & Revenue & $\begin{array}{l}\text { Profit After } \\
\text { Tax (PAT) }\end{array}$ & $\begin{array}{l}\text { Earnings Per } \\
\text { Share (EPS) }\end{array}$ & CSR Costs \\
\hline 2012 & 298,454 & 145,024 & 8.52 & 4,033 \\
2013 & 386,177 & 201,198 & 11.85 & 1,880 \\
2014 & 391,639 & 159,501 & 9.42 & 2,129 \\
2015 & 491,725 & 181,323 & 10.86 & 722 \\
2016 & 615,103 & 186,624 & 11.34 & 1,097 \\
\hline
\end{tabular}

Source: Dangote Cement Plc, annual reports and accounts (2012-2016).

$R Q$ 1: Is there a relationship between increase in revenue in the last 5 years and CSR investment of Dangote Cement Plc?

The first research question analyzes whether there is a relationship between increase in revenue in the last 5 years and CSR investment of Dangote Cement Plc as shown in the tables below.

Table 2. Revenue Evolution and Growth.

\begin{tabular}{lll}
\hline Year & Revenue(\#' Million) & Percentage (\%) \\
\hline 2012 & 298,454 & 13.7 \\
2013 & 386,177 & 17.7 \\
2014 & 391,639 & 17.9 \\
2015 & 491,725 & 22.5 \\
2016 & 615,103 & 28.2 \\
\hline
\end{tabular}

From table 2 above, there was a steady increase in revenues through the 5 -year period. The figures for the year 2012 was $12 \%$ of the total figures for the period analyzed; for 2013 , it was $17.7 \%$, which is an increase of $29 \%$ from 2012 ; for 2014 , it was $17.9 \%$ of the total figures, which is a $1 \%$ increase from the previous year; for 2015 , it was $22.5 \%$, which is an increase of $26 \%$ from the year before; and for 2016 , it was $28.2 \%$ of the total figures, which is a $25 \%$ increase from the previous year's figures. This steady increase in revenue can be credited to the involvement in CSR activities by Dangote Cement Plc.

Table 3. Relationship between Increase in Revenue and CSR Investment Using the R-Square.

\begin{tabular}{ll}
\hline & Revenue(N'million) \\
\hline $\mathrm{R}$ & 0.6781 \\
Relationship & $+\mathrm{ve}$ \\
\hline
\end{tabular}

Source: SPSS output analyzed from financial reports of Dangote Cement Plc

The table 3 above depicts the Relationship between Revenue and CSR investment of Dangote cement Plc Using
$\mathrm{R}^{2}$, a positive relationship could be seen to exist between increase in Revenue and CSR investment of Dangote cement $\mathrm{Plc}$, as the $\mathrm{R}^{2}$ value is positive. This analysis clearly satisfies condition, which states that if $\mathrm{R}^{2} \geq 0$, then a positive relationship exists. Thus, Revenue shows $67.81 \%$ degree of relationship.

$R Q$ 2: Is there a relationship between changes in profit after tax (PAT) in the last 5 years and CSR investment of the Dangote Cement Plc?

The second research question analyzes whether there is a relationship between increase in profit after tax (PAT) in the last 5 years and CSR investment of Dangote Cement Plc as shown in the tables below.

Table 4. Net Profit Evolution and Growth.

\begin{tabular}{lll}
\hline Year & Profit After Tax (\#' Million) & Percentage (\%) \\
\hline 2012 & 145,024 & 16.6 \\
2013 & 201,198 & 23.0 \\
2014 & 159,501 & 18.3 \\
2015 & 181,323 & 20.8 \\
2016 & 186,624 & 21.4 \\
\hline
\end{tabular}

From Table 4 above, there was an increase in PAT between 2012-2013 and between 2014-2016. However, there was a decline between 2013-2014. The figures for the year 2012 was $16.6 \%$ of the total figures for the period analyzed; for 2013 , it was $23.0 \%$, which is an increase of $39 \%$ from 2012 ; for 2014 , it was $17.9 \%$ of the total figures, which is a $20 \%$ fall from the previous year; for 2015 , it was $20.8 \%$, which is an increase of $14 \%$ from the year before; and for 2016 , it was $21.4 \%$ of the total figures, which is a $3 \%$ increase from the previous year's figures. Dangote Cement Plc could credit this increase in PAT to the involvement in CSR activities.

Table 5. Relationship between Increase in Profit After Tax and CSR Investment Using the R-Square.

\begin{tabular}{ll}
\hline & Profit After Tax(N'million) \\
\hline $\mathrm{R}$ & 0.5428 \\
Relationship & $+\mathrm{ve}$ \\
\hline
\end{tabular}

Source: SPSS output analyzed from financial reports of Dangote Cement Plc

The table 5 above depicts the Relationship between Profit after Tax (PAT) and CSR investment of Dangote cement Plc Using $\mathrm{R}^{2}$, a positive relationship could be seen to exist between increase in PAT and CSR investment of Dangote cement Plc, as the $\mathrm{R}^{2}$ value is positive. This analysis clearly satisfies condition, which states that if $\mathrm{R}^{2} \geq 0$, then a positive relationship exists. Thus, Profit after Tax (PAT) shows $54.28 \%$ degree of relationship.

$R Q$ 3: Is there a relationship between changes in earning per share (EPS) in the last 5 years and CSR investment of the Dangote Cement Plc?

The third and last research question analyzes whether there is a relationship between increase in earnings per share (EPS) in the last 5 years and CSR investment of Dangote Cement Plc as shown in the tables below. 
Table 6. Shareholders Earnings Evolution and Growth.

\begin{tabular}{lll}
\hline Year & Earnings Per Share(EPS) & Percentage (\%) \\
\hline 2012 & 8.52 & 16.4 \\
2013 & 11.85 & 22.8 \\
2014 & 9.42 & 18.1 \\
2015 & 10.86 & 20.9 \\
2016 & 11.34 & 21.8 \\
\hline
\end{tabular}

From Table 6 above, there was an increase in EPS between 2012-2013 and between 2014-2016. However, there was a decline between 2013-2014. The figures for the year 2012 was $16.4 \%$ of the total figures for the period analyzed; for 2013 , it was $22.8 \%$, which is an increase of $39 \%$ from 2012 ; for 2014 , it was $18.1 \%$ of the total figures, which is a $21 \%$ fall from the previous year; for 2015 , it was $20.9 \%$, which is an increase of $15 \%$ from the year before; and for 2016 , it was $21.8 \%$ of the total figures, which is a $4 \%$ increase from the previous year's figures. Dangote Cement Plc could credit this increase in EPS to the involvement in CSR activities.

Table 7. Relationship between Increase in Earnings Per Share (EPS) and CSR Investment Using the R-Square.

\begin{tabular}{ll}
\hline & Earnings per share \\
\hline $\mathrm{R}$ & 0.6079 \\
Relationship & $+\mathrm{ve}$ \\
\hline
\end{tabular}

Source: SPSS output analyzed from financial reports of Dangote Cement Plc

The table 7 above depicts the Relationship between Earnings Per Share (EPS) and CSR investment of Dangote cement Plc Using $\mathrm{R}^{2}$, a positive relationship could be seen to exist between increase in EPS and CSR investment of Dangote cement Plc, as the $\mathrm{R}^{2}$ value is positive. This analysis clearly satisfies condition, which states that If $R^{2} \geq 0$, then a positive relationship exists. Thus, Earnings Per Share (EPS) shows $60.79 \%$ degree of relationship.

This research empirical result is similar to the findings of Ekatah et al, (2011) which found a positive relationship between CSR and profitability of Royal Dutch Shell Plc. This is also consistent with the results of other studies $[16,31,25$, $35]$.

\section{Conclusion}

The findings to the research questions had shown that there is a positive relationship between CSR and profitability. Therefore, Dangote Cement Plc CSR investments have positive impact on profitability performance indicators such as Revenue, Profit after tax and Earnings per share for the studied period (2012-2016). This study has a number of limitations, which could be used to further research into the area. The study used only one company i.e. Dangote Cement Plc and the accounting reports over a limited time span. Further research could be done into other large Cement companies in the world and for a longer times span.

\section{References}

[1] Aaronson, S. A., (2003) "Corporate responsibility in the global village: The British role model and the American laggard". Business and society review, 108 (3), pp 309318.

[2] Ademosu, E. A., (2008) "Corporate social responsibility: The experience of the Nigeria banking system" http://www.acamb.com. Accessed February 12, 2017.

[3] Amole, B. B., Adebiyi, S. O., and Awolaja, A. M., (2012) "Corporate social responsibility and profitability in Nigeria banks: A causal relationship". Research journal of finance and accounting, 3 (1), pp 6-17.

[4] Arias, J. C., and Petterson, K. (2009) "Relationship between corporate social responsibilities' promotion and corporate performance in the multinational corporations". Business intelligence journal, 2 (1), pp 93-112.

[5] Aupperle, K. E., Carroll, A. B., and Hatfield, J. D. (1985) “An empirical examination of the relationship between Corporate Social Responsibility and profitability". Academy of Management journal, 28 (2), 446-463.responsibility and profitability." Academy of Management Journal, 28 (2): 446463.

[6] Babalola, Y. A (2012) "The impact of corporate social responsibility on firms' profitability in Nigeria". European Journal of Economics, Finance and Administrative Sciences, ISSN 1450-2275 Issue 45.

[7] Bell, E. and Bryman, A. (2003) "Business Research Methods". New York, Oxford University Press Inc..

[8] Bowman, E. H. and Haire, M. (1975) "A strategic posture toward corporate social responsibility", California Management Review, 18, 49-58.

[9] Choi, J., Kwak, Y., and Choe, C. (2010) "Corporate social responsibility and corporate financial performance": Evidence from Korea. Australian journal of management, 35 (3), pp 291-311.

[10] Cochran, P. L, and Wood, R. A (1984) "Corporate social responsibility and financial performance". Academy of Management journal, 27 (1), 42-56.

[11] Dumay, J. (2016) "A critical reflection on the future of intellectual capital": From reporting to disclosure. Journal of Intellectual Capital, 17 (1), 1-17.

[12] Ekatah, I.; Samy, M.; Bampton, R. and Halabi, R. (2011) "The Relationship between Corporate Social Responsibility and Profitability: The Case of Royal Dutch Shell Plc", Corporate Reputation Review, Macmillan Publishers Ltd., Vol. 14, No. 4, pp. 249-261.

[13] Fombrun, C. J. (1996) "Reputation: Realizing value from the corporate image": Harvard Business Press.

[14] Friedman, M. (2007) "The social responsibility of business is to increase its profits". Corporate ethics and corporate governance, 173-178.

[15] Friedman, M. (2008) "The social responsibility of business in to increase its profits". New York Times Magazines, 13 Sept., 32-33. 
[16] Freeman, R. and Gilbert, D. Jr. (1987) 'Managing stakeholder relations', in S. Prakash and C. Falbe, (eds.), Business and Society: Dimensions of Conflict and Cooperation, Lexington Books, Toronto, Canada, pp. 397-422.

[17] Gray, R. (2006) "Social, environmental and sustainability reporting and organizational value creation whose value? Whose creation?" Accounting, Auditing \& Accountability Journal, 19 (6), 793-819.

[18] Greening, D. W., and Turban, D. B. (2000) "Corporate social performance as a competitive advantage in attracting a quality workforce". Business \& Society, 39 (3), 254-280.

[19] Iqbal, N., Ahmad, N., Basheer, N. A., and Nadeem, M., (2012) "Impact of corporate social responsibility on financial performance of corporations": Evidence from Pakistan. International journal of learning and development, 2 (6), pp 107-118.

[20] Jamali, D., and Mirshak, R., (2007) "Corporate social responsibility: Theory and Practice in a developing country context". Journal of business ethics, 72, pp 243-262.

[21] John, E. A, John, A. O and Adedayo, O. E (2013) "Corporate social responsibility and financial performance: Evidence from Nigerian manufacturing sector", Asian Journal of Management Research, V. 4, no. 1.

[22] Lee, D. D., Faff, R. W. and Langfield-Smith, K. (2009) Revisiting the Vexing Question: Does Superior Corporate Social Performance Lead to Improved Financial Performance? Australian Journal of Management, 34 (1), pp. 21-49.

[23] Margolis, J. D., \& Walsh, J. P. (2003). "Misery loves companies: Rethinking social initiatives" by business. Administrative Science Quarterly, 48 (2), 268-305.

[24] Marom, I. Y. (2006) "Towards a unified theory of the CSPCFP link", Journal of Business Ethics, 67, 191-200.

[25] McGuire, J., Sundgren, A. and Schneeweis, T. (1988) "Corporate social responsibility and firms financial performance", Academy of Management Journal, 31, 854872.

[26] McWilliams, A., and Siegel, D. (1997) "The role of money managers in assessing corporate social responsibility research". The Journal of Investing, 6 (4), 98-107.

[27] McWilliams, A., and Siegel, D. (2001) Corporate social responsibility: A theory of the firm perspective. Academy of management review, 26(1), 117-127.

[28] Moskowitz, M. (1972) "Choosing socially responsible stocks". Business and Society Review, Saunders, M. and Lewis, P. (2012) Doing Research in Business and Management: An essential guide to planning your project. 5th Ed. Pearson Education Limited.

[29] Okeowo, Alexis (7 March 2013). "Africa's Richest Man, Aliko Dangote, Is Just Getting Started”. Bloomberg. Retrieved 25 March 2017 from: https://en.wikipedia.org/wiki/Dangote_Group.

[30] Orlitzky, M., Schmidt F. L. and Rynes S. L. (2003) "Corporate social and financial performance: A meta-analysis". Organization Studies, 24 (3), pp.403-41.

[31] Parker, R. and Eibert, H. (1975) 'Social responsibility: The underlying factors', Business Horizons, 18, 53-66.

[32] Roman, R. M., Hayibor, S. and Agle B. R. (1999) "The relationship between social and financial performance: repainting a portrait”. Business and Society, 38 (1), pp.109-25.

[33] Ruf, B. M., Muralidhar, K., Brown, R. M., Janney, J. J. and Paul, K. (2001) "An empirical investigation of the relationship between change in corporate social performance and financial performance": A Stakeholder Theory Perspective. Journal of Business Ethics, 32, pp.143-56.

[34] Tsoutsoura, M. (2004) 'Corporate social responsibility and financial performance', Working paper. Haas School of Business, University of California at Berkeley Applied Financial Project.

[35] Waddock, S. A., \& Graves, S. B. (1997) "The corporate social performance". Strategic management journal, 8 (4), 303-319.

[36] Zakari, M. (2006) "An Assessment of Depreciation Practice in Nigeria Commercial Banks". Unpublished project, for a partial fulfillment for the award of bachelor degree, Bayero University Kano, Nigeria. 